\title{
"Commit To Faithful Brethren Who Are Able To Teach" (2 Timothy 2:2): The Pastor/Preacher As A Leader In Disciple Making
}

\begin{abstract}
Many have come to associate discipleship process in the church with Bible studies. As such, preachers pay little attention to disciple making in their delivery with the assumption that preaching time is not the time to build up disciples. Some preachers are also affected by postmodernism, capitalism, and secularization-individualism and as such want to project themselves only and think about what they can get. They forget that biblical leadership is about building others and developing other people's faith in Jesus Christ so that they grow to maturity. Preachers who do not see the need to build others and overlook committing the word to them cannot be ideal leaders of the church. Bearing in mind that the key role of the pastor is preaching, this paper emphasizes the role of the preacher in disciple making. It argues that for effective disciple making, the preacher must intentionally aim at committing the message to others who have the capacity to teach others too in order to have a multiplicative effect. Using the practical theology approach, the paper demonstrates that when a preacher builds relationships intentionally, lives a life of integrity, and builds up knowledge, the command to commit the word to faithful brethren can be fulfilled.
\end{abstract}

Keywords: Preacher, discipleship, leadership, commitment, faithful brethren.

\author{
JOHN ABEDU QUASHIE \& \\ MARK S. AIDOO ${ }^{1}$ \\ ${ }^{1} J o h n$ Abedu Quashie (PhD) is a \\ Lecturer in Practical and Pastoral \\ Theology, the Dean of Students, \\ and Director for Professional \\ Programmes at Trinity Theo- \\ logical Seminary, Legon, Ghana. \\ Email: jaquashie@yahoo.com \\ Mark S. Aidoo (PhD) is a \\ Lecturer in Old Testament \\ and Hebrew, and Director for \\ Research at Trinity Theological \\ Seminary, Legon, Ghana. \\ Email:macsaidoo@gmail.com
}

\section{Manuscript}

Received 27th April 2020,

Accepted 1st June 2020,

Published online 22nd June 2020.

\section{INTRODUCTION}

The Christian life involves a cycle of sharing, especially within the context of teaching and learning. Christian leaders need to teach others to grow and also have to learn to grow by learning from others. Sharing the word of God begins when people have been accepted into the body of Christ. The grand, unchallenged purpose of God's gracious rescue of humankind is for his pleasure and glory so that believers become disciples of Christ and are guided to grow into the likeness of Christ. The cycle of teaching and learning in the church is generally coordinated by the leaders of the church which includes apostles, prophets, evangelists, pastors and teachers (Eph 4:11). Nevertheless, the responsibility to encourage growth in the church as well as discipleship has not only been laid on these fivefold gifted leaders but also on others. Even though it is the pastor who has ultimate responsibility for discipleship and growth in the church, discipleship is not work done by only pastors. It does not also take the pastor's alone to engage in discipleship. Problems arise when members who have little knowledge and skill of preaching are engaged as volunteers to help spread the word of God for others to grow in the body of Christ. Very often, such preachers end up not helping the church in its discipleship process. This paper discusses an aspect of the role of the pastor/preacher in disciple making. It argues that for effective disciple making the pastor/preacher, in addition to preaching to the generality of church, must aim at committing the message to others with the capacity to teach in order to have a multiplicative effect.

The approach for this paper is from the perspective of a Christian practical theologian. Practical theologians focus on the practice of the church, examine and interpret essential Christian practices from a theological or normative 
perspective. ${ }^{2}$ The practice of preaching which falls under practical theology borrows insights from biblical studies, systematic theology, communication theories, human psychology etc., to integrate modern understandings of human and faith development. Bearing in mind that the church is structured in particular cultures or societies and there is no such thing as a culture-less congregation, a look at the Ghanaian Christian culture, values, social structures, and attitudes would be necessary to propose a pattern of pastoral/preaching ministry in which developing others to also preach and teach becomes a key aspect in disciple making. Frank Burch Brown is right when he says: "As religion develops, it must orient itself both in relation to the culture of its origin and in relation to the contemporary cultures it encounters - each of which presents alternative possibilities that religion may reject, modify, or eventually adopt." ${ }^{3}$ So one turns to contemporary times to examine how the pastoral/preaching task is executed.

\section{The Face of Preaching in Contemporary Times}

The ordained pastor of the church is basically a preacher. Other persons who are not ordained are also appointed to preach. The pastoral ministry which involves preaching usually comes with so many challenges. A.D. Litfin has noted that there are few vocations which splinter a person and one of them is the pastoral ministry. The pastor can easily lose focus or get lost in the shuffle in the course of working. ${ }^{4}$ Pastors easily conform to the world's standards making them side-track from their calling and mission and that affects the way they preach. Ryan Lamothe states four factors, namely, postmodernism, capitalism, secularization-individualism, and lack of self-identity, as the bane of the church. Although he wrote from the perspective of the United States of America, these factors are present in the case of Ghana and Africa. The church in Ghana is affected by postmodernism, capitalism, and secularization-individualism. Lamothe observed that postmodern people hold the view that their stories are superior or ultimate, even within the social reality of competing values and claims. An individual can consider a way of life as acceptable and would not care what others may say. Wrongdoing is relative concept. "Their self-certainty, in other words, screens anxiety associated with a postmodern vulnerability. The world, regardless of one's attempt to retreat into simplicity, is a more complex, ambiguous, and uncertain place." ${ }^{5}$ On capitalism, Lamothe explains how the capitalistic symbol comprised of seeking private ownership, improving productivity for the sake of the shareholders, accumulation of wealth that foster acquisitiveness, zero-sum competition, and materialism is causing harm to the church. The focus on competition, profit, controlling the factors of production disrupt the meanings and values in relationships of which the church cannot be an exception. ${ }^{6}$ Individualism is also a concern Lamothe raised. It creates a tendency where people insist on finding their true selves independently at the expense of others. ${ }^{7}$

The rise of independent churches in Ghana can be a clear example. Each wants to claim that what he or she is saying is superior to what others say. A particular preacher alone should be heard because his or her knowledge is unparalleled. Those who are individualistic do not see any good in another person and would not submit to any outside authority. If they are preachers, they want to gain all the fame for themselves and amass wealth, appear outstanding for the sake of the ministry. They think about themselves only and how they can make a name for themselves. So, they are always on the platform and pulpits sharing the word of God. When another person preaches well, they try to take the glory away from that person to themselves by showing that they have an input in the success of the one who preached. The current postmodern society has embraced relativism and secular humanism after rejecting all absolutes. It wants to assert that truth is relative so each church or preacher can do what seems best. Regardless of this postmodern nature of contemporary society, the church should remember that preaching is an art and a scientific act that must follow some basic principles.

One common mistake found in the church is the assumption that all understand how the church functions and thus all can contribute in the mission of the church. ${ }^{8}$ People who are not well trained and uncommitted are making their voices heard and directing the pace. Quashie calls them "imposters." Some preachers seem to be preaching to be seen rather than to be heard. They like to change their accents in speaking so they become someone else other than

\footnotetext{
See Christiaan A. M. Hermans "From Practical Theology to Practice-oriented Theology: The Study of Lived Spirituality and lived Religion in late Modernity," International Journal of Practical Theology 18.1 (2014): 114. DOI: https;//doi.org/10.1515/ijpt-2014-0009; Kathleen A. Cahalan, "Three Approaches to Practical Theology, Theological Education, and the Church's Ministry." International Journal of Practical Theology, 9. 1 (2005): 64.

Frank B. Brown, "Christian Theology's Dialogue with Culture," in Companion Encyclopaedia of Theology, eds., Peter Byrne and Leslie Houlden (New York: Routledge, 1995), 314.

4 A. Duane Litfin, "The Nature of the Pastoral Role: The Leader as Completer," Bibliotheca Sacra 139.553 (1982): 57.

5 Ryan Lamothe, "Reflections on Pastoral Leadership in the Face of Cultural-Communal 'Ruin'," The Journal of Pastoral Theology 20.1 (2010): 3 .

6 Lamothe, "Reflections on Pastoral Leadership," 4.

Ibid., 7.

James D. Berkley, Leadership Handbook of Management and Administration (Grand Rapids: Christianity Today Inc,1994), 246.

9 John A. Quashie, "Imposters in the Pulpits: A Critique of Preaching in Contemporary Ghanaian Christianity", Orita: Ibadan Journal of Religious Studies, 46.1 \& 2 (June \& December 2014): 35.
} 
themselves. It is not a bad idea to borrow words you hear from a mentor or another preacher. The problem is when one begins to change their voice to sound like the mentor or another person. Some want to speak like Americans. The "imposters" also seem to be propounding theories rather than the practical word of life that the people need to lead their daily lives. They love to use big words and philosophical ideas in preaching. It is known that when someone who does not understand a particular language hears others communicating in that language, it makes no meaning to such a person and thus cuts the person who does not understand that language off. The same happens when preachers who love to speak Hebrew and Greek, or apply other technical jargons used in particular fields and not common to the ordinary person in the pews. Although it is the word of God which must accomplish the purpose for which it is sent, it will achieve little results because the audience cannot understand.

Biblical preaching does not aim at stirring people's emotions to make them happy and laugh. If preachers are really talking about sin, why should the audience laugh? Preaching is not to enlighten their minds or to satisfy their imagination simply because the people must be taught. Preachers must distinguish the difference between teaching and preaching, although there is an element of teaching in every preaching. At times, the preacher wants to sound jovial and act in a way that would elicit the emotions of the audience. One can often see an audience clapping or standing, shouting "preach on" as the preacher rants and rows. At times, the focus is what sounds good in their ears. In contrast to these, it must be noted that the objective of preaching is to: (1) Facilitate an encounter with God through the word; (2) Seek to bring people to a definite commitment to God through Christ Jesus; (3) Demand a verdict, a response to the message; and (4) Empower people to do what is good. ${ }^{10}$

Some would not want to preach when the numbers are not many. They want a full house before they can be motivated to preach. They hardly see that the quorum for God to be present is two or three (Matt 18:20). They hardly have compassion on those who are present and focus their attention on those who are not there. Many people hear what the preacher says but cannot remember what the preacher said. They leave the scene without any decision and not knowing the new action they have to take in their lives. This is because the people are not guided to learn during preaching. Preaching is not beneficial when the big idea is not clearly stated and driven home. As Graham Johnston points out:

One common sermonic flaw is the preacher's failure clearly to define the thrust of the message. Without some definition, some clarity on the issues tackled, the sermon rambles from one idea to the next like a bumper car with an eight-year-old behind the wheel. What will hold together your sermon for postmoderns is what holds together any motion picture or play - various acts blending to form one overall assertion. ${ }^{11}$

Effective preachers lead the people to make a decision to follow Christ in particular ways and clearly say what the listener must take home so that the listener leaves the place not only "knowing" what has been said, but what is to be "done".

The preacher has a duty to preach so that people grow into the likeness of Christ. MacArthur states that "pastoral leadership is to guard and shepherd the flock of God, which includes all that it takes to bring the church to maturity." 12 To bring an individual or a church to maturity, the role of the preacher cannot be overlooked or dealt with less than fully. A healthy church is one that engages in genuine worship, is led by a competent devoted Christian minister, nurtured by a faithful preacher, stresses discipleship, involves all the members in ministry, and serves the community to transform it. A healthy church is also one in which the church members individually and corporately are involved to meet others' needs and demonstrate Christ's love. Equally important, however, is one which feeds its members with the unadulterated Word of God through a strong biblical teaching and preaching, and constantly seeking guidance from the Holy Spirit and God's Word. If the church in Ghana is to be a healthy church, effective preaching must take place through formal and informal teaching and learning processes.

\section{Making Disciples in the Church}

The word "disciple" generally denotes a "student," "pupil," "apprentice," or "adherent," as opposed to a "teacher." It was common in the ancient world for learners to sit under the feet of a great religious leader or teacher of philosophy and thus become the follower. The Greek word mathètès translated as "disciple" has the same root for the word "mathematics", which is the science of solving problems by developing theories and theorems to shape life through logical reasoning. The teacher of the disciple has a duty to help the learner understand life so as to solve problems. The word "disciple" is not explicitly used in the Old Testament and likewise the term mathētess does not occur in the Greek translation of the Old Testament, that is, the Septuagint. This does not mean, however, that the concept and practice is not there. Terms

\footnotetext{
10 John A. Quashie \& Mark S. Aidoo, Biblical Preaching in a Contemporary African Setting: An Introduction (Tema: Kabkork Publications, 2018), 56

11 Graham Johnston, Preaching to a Postmodern World: A Guide to Reaching Twenty-first Century Listeners (Grand Rapids: Baker Books, 2001), 172.

12 John MacArthur, Pastoral Ministry: How to Shepherd Biblically (Nashville, TN: Thomas Nelson, 2005), 233.
} 
like a teacher or prophets and the followers abound (1 Kgs 20:35; $2 \mathrm{Kgs} \mathrm{2:3-15;4:1-38).} \mathrm{Second} \mathrm{Isaiah} \mathrm{likens} \mathrm{the} \mathrm{act} \mathrm{of}$ discipleship to God waking him up every morning and giving him attentiveness so that he can listen and learn (Is 50:4). A disciple is a "learner," or on a more committed level, an "adherent." The Sophists also used the term to refer to an "institutional pupil." At the time of Jesus, disciples were more often an "adherent" of some teacher. ${ }^{13}$ Wilkins observes the commitment of the learner to the teacher saying: "The type of adherence was determined by the master, ranging from being the follower of a great thinker and master of the past like Socrates, to being the pupil of a philosopher like Pythagoras, to being the devotee of a religious master like Epicurus." ${ }^{14}$ Hence, one cannot be a disciple without a level of commitment.

The disciple is a person who is learning from the master to become just like the master. A disciple is someone who is living out the decision to follow Christ in everyday life. Michael Wilkins defines disciple as, "the primary term used in the Gospels to refer to Jesus' followers and is a common referent for those known in the early church as believers, Christians, brothers/sisters." ${ }^{15}$ A disciple can be compared to an apprentice or pupil attached to a master. The apprentice pledges allegiance to learn instruction and be committed to the master. ${ }^{16}$ All apprentices who are committed grow to become masters. In other words, one qualifies to be a disciple if the person appears to uphold some level of commitment and allegiance, believes in what the master says and tries to follow it. Robert L. Foster, drawing from the concept of discipleship in the ancient Hellenistic world, claims that a disciple was a pupil or learner of a great teacher. Thus, it is the duty of a disciple to devote to the teachings of a great teacher or exemplified by a particular culture or city. ${ }^{17}$ Watson claims that a boy of thirteen years would have completed the basic formal education but may continue his study of the Torah in a small group or seek to study as a disciple under a certain scholar to be a scholar. ${ }^{18}$ An example could be seen in the life of Paul who studied the Law under the tutelage of Gamaliel, a famous Rabbi in Jerusalem (Acts 5:34;22:3). Discipleship is a relational process of helping someone grow spiritually from childhood to maturity. It is done by building the principles of God's Word into a person's life so that such a person is equipped to understand and follow the prompting of the Holy Spirit in knowing how to respond to any situation with Christ-like attitudes and actions.${ }^{19}$ The learner-disciple grows into a mature disciple, integrating in his or her their faith and life obedience to help others.

A master who does not have followers has no worth, and the same can be applied to a preacher. Robert Weber defines discipleship as "the process of making disciple." ${ }^{20}$ Discipleship refers to the "intentional training of disciples with accountability, on the basis of loving relationships." ${ }^{\text {21 }}$ It is "the full-orbed process of seeing people come to faith in Christ, grow in Him, and then being equipped to go back and help others repeat this process." 22 The teacher must be a person who knows Christ inwardly and is committed to living outwardly in love and obedience to Him. Thus, as the disciple is taught, he or she begins to live like Jesus. Hence, the goal of discipleship is not simply to be a master but to bring people to conformity to the highest standard, maturity to the fullest degree and ethical completeness just like Christ in the context of the community (Rom 8:28-29). Christian discipleship is not just a one-time relationship but a daily commitment to following Christ. A Christian is one who becomes adherent of Christ, whose daily life and behaviour in facing adversity is like Christ. ${ }^{23}$ Jesus taught his disciples over a three-year period, by setting the pattern by which future disciples should walk. He taught with authority and power and with higher morality ethics. In the view of James Montgomery Boice, there are five elements of discipleship which Jesus expected: obedience, repentance, submission, commitment, and perseverance. ${ }^{24}$ Through these elements, disciples make other disciples.

The idea of Jesus calling the disciples to himself for a special purpose is evident in his initial call. He summoned his disciples saying, "follow me, and I will make you fishers of men" (Matt 4:19; cf Mk 1:17; NRSV). Jesus appointed the Twelve so that they might eventually be sent out to preach (Mk 3:14). The initial comment about reaching men was

13 Gary C. Newton, Growing toward Spiritual Maturity (Wheaton: Evangelical Training Association, 1999 ), 15.

14 Michael J. Wilkins, "Disciples," in Dictionary of Jesus and the Gospels, ed. Joel B. Green, Scot McKnight, and I. Howard Marshall (Downers Grove, IL: InterVarsity, 1992), 176.

15 Michael J. Wilkins, Following the Master: A Biblical Theology of Discipleship (Grand Rapids, MI: Zondervan, 1992 ), 40 quoted in Mark Richard Brown, "By This They Will Know: Discipleship Principles to Transform the Church" (Unpublished Thesis, Virginia: Liberty Baptist University Theological Seminary, 2012), 6.

16 The HarperCollins Bible Dictionary (New York: HyperCollins 1996), 242.

17 Robert L. Foster, "Discipleship in the New Testament," date accessed 26 June 2017 in http://www.sbl-site.org/eductional/teachingbible.aspx

18 D. F. Watson, "sv Education: Jewish and Greco-Roman," in Dictionary of New Testament Background, ed. Craig A. Evans and Stanley E. Porter (Downers Grove, IL: InterVarsity, 2000), 308-313.

19 International Leadership Institute, National Conference: Eight Core Values for Christian Leadership (Carrolton: International Leadership Institute, 2015), 113.

20 Robert E. Weber, Ancient-Future Evangelism: Making Your Church a Faith-Forming Community (Grand Rapids: Baker Books, 2003$)$, 41.

21 Bill Hull, The Disciple-Making Church: Leading a Body of Believers on the Journey of Faith (Grand Rapids: Baker Books, 2010$), 36$.

"What is Disciple-Making?" Sonlife Classic, accessed May 1 2017, http://sonlifeclassic.com/what-is-disciple-making/

3 Chard Brand, Charles Draper, Archie England, "sv Christian," in Holman Illustrated Bible Dictionary (Nashville, Tennessee: Holman Bible Publishers, 2003), 288.

24 James Montgomery Boice, Christ's Call to Discipleship (San Francisco: Kregel, 1998), 29. 
reasserted as a command in Matthew 28. It must be noted that "go" is not an imperative in Matthew 28:19-20. The Greek word poreuthententes translated in English as "go" is a participle; it ends with "ing" translation. This means that the word means "going", make disciples. It could also be rendered as, "As you go", make disciples. However, the idea of making a disciple is fleshed out more in the idea of preaching within which the believers can be taught to obey all things Jesus commanded.

The unveiling of the mystery of Christ in preaching takes place when Christ resides in the spirits of human beings, and fusing all believers into a supernatural organism, called the church. Disciple making, like preaching, is not a programme or activity of the church but rather the church is the outcome of disciple making and preaching. The church exists because of the significance of preaching. The thrust of the Great Commission is not just to make converts but to make disciples (Matt 28:18-20). To make disciples, the main command has to do with teaching. Teaching believers to obey must be daily exercise. It is the most important ongoing ingredient for a meaningful Christian life. ${ }^{25}$

The need is to be more intentional at efforts in disciple making. The formula for discipling the world and the methodology required to bring reproduction and multiplication to world mission is how the Word is committed to those who are discipled and are faithful. Even though worship, evangelism, and social action are all important, without preaching and teaching, these activities are incomplete. What then is the role of the pastor/preacher in disciple making?

All too often, many have assumed that discipleship can be effective only through Bible studies in small groups or on one-to-one basis. Chris Shirley argues that disciples are developed in a variety of contexts: learning in classrooms, sharing with fellow disciples, worshipping in the congregation, working on the mission field, serving in ministry, relating to mature role models, and maturing in a family setting, and the best place for bringing all these options together to achieve the desired goal is the local church. ${ }^{26}$ But the one who leads the local church is the pastor. This makes the work of the pastor more in line with disciple making. The church has responsibility to teach, exhort, and encourage, rebuke and discipline one another and the pastor cannot leave himself or herself out. It is only when pastors understand their role of preaching in influencing people to become what God wants them to be that discipleship can be complete.

\section{The Pastor as a Preacher}

The pastor plays a leadership role in building the body of Christ and one of the key roles of the pastor is preaching. As a preacher, the pastor who has been given a privilege to preach must see it as an opportunity to invite, identify and lead others to be faithful so that the word of God can be committed to them. This is a critical leadership role of the pastor. Leadership has been defined from different perspectives and disciplines. Definitions are often biased towards interest and what is hoped to be achieved. To Peter G. Northouse, leadership concerns itself with the person of the leader and the dynamics between leaders and followers that result in a form of influence. ${ }^{27}$ James Baker suggests that "leadership is knowing what needs to be done ... and getting it done." ${ }^{28}$ His definition implies that leadership and its effectiveness relates to accomplishment of a task. J. Oswald Sanders sees leadership as "the ability of one person to influence others to follow his or her lead." ${ }^{29}$ From another viewpoint, Bernard Montgomery speaks of leadership as "the capacity and will to rally men and women to a common purpose, and the character which inspires confidence." ${ }^{30}$ People will ordinarily not avail themselves. It only takes a leader to make them available. Leadership is also defined with emphasis on some refined leadership behaviours namely: "contextual thinking, directional clarity, creative assimilation, reciprocal communications, change orchestration, drive and perseverance." 31

J. Robert Clinton also is of the view that biblical leadership is "a dynamic process in which a man or woman with God-given capacity influences a specific group of God's people toward His purposes for the group." 32 To add to this, J. B. Ciulla states that "Christian leadership is not a person or a position, but rather a complex moral relationship between people, based on trust, obligation, commitment, emotion, and a shared vision of the good." ${ }^{33}$ Hence, the pastor's task as a preacher is not only towards the whole of the congregation but to influence others, often a few, direct them and build their capacities. A preacher who does not know who to influence needs a lot of help. Likewise, a preacher who does not see the need to commit the word to others is not a good leader. Every sermon must have some focus on persons who are trustworthy and have the capacity to teach others.

25 Bill Hull, The Disciple-Making Pastor: Leading Others on the Journey of Faith (Grand Rapids: Baker Books, 2007), 69.

26 Chris Shirley, "It takes a Church to make a Disciple: An Integrative Model of Discipleship for the Local Church," Southwestern Journal of Theology, 50. 2 (Spring 2008): 223.

27 Peter G. Northouse, Leadership: Theory and Practice (Thousand Oaks: Sage, 2004),51

28 James Baker, former US Secretary of State, "Coalition Building during the Gulf War" (speech, October 26, 2001).

29 J. Oswald Sanders, Spiritual Leadership (Chicago: Moody Publishers, 2007), 29.

30 Bernard Law Montgomery, Memoirs of Field-Marshal Montgomery (Cleveland: World Press, 1958), 70.

31 "Human Resource Development Press" 2004. Accessed January 13, 2020. www.hrdpressonline.com/product_info/leadership_effectiveness_ profile.htm.

32 Robert J. Clinton, The Making of a Leader (Colorado Springs: Navpress, 1988), 14.

33 J. B. Ciulla, (ed.), Ethics, the Heart of Leadership (Westport: Praeger Publishers, 2004), 66. 
In all, pastoral leadership must be built on God, faith in Jesus Christ and towards the development of people's faith in Jesus Christ. This is the premise on which a theology of leadership can develop. By implication, pastoral leadership is concerned with developing people to follow God through faith in Jesus and in the power of the Holy Spirit. With pastoral leadership, the emphasis is on Christian ethics with its acknowledgment of the divine and recognition of the Bible as a key ingredient in moral formation and ethical decision-making.

Robert Clinton states that "church leadership is a dynamic process in which a man or woman with God-given capacity influences a specific group of God's people toward His purposes for the group." ${ }^{34}$ Again, J.E. Means is of the opinion that "church leadership exists to guide the church to spiritual vitality, unity, and effective ministry." ${ }^{35}$ The apostles began to preach the great truths about Jesus Christ by showing their distinctively Jewish congregation how the Old Testament prophets showed he was the Messiah. They provided the right message about Jesus' teaching on life, death, and the eternal state. It is through their preaching that others heard the message. Paul notes that faith comes by hearing the Word of God (Rom. 10: 17) and Jesus himself is the Word (John 1:1). An effective pastor/preacher needs to develop a deep concern about sharing the word with the learners who have come to listen to the word of God. The pastor/preacher must pay attention to the life concerns of the learners and the experiences they go through and use the truth about the Word of God to guide them. The truth should not be the relative truth but the absolute truth.

A preacher needs to develop a strong relationship with the the audience or group members who listen to the sermons. This can be achieved through daily prayer and reflection, study of Scripture, participation in worship, and involvement in service activities. The preacher must help them build an open, supportive Christian community. Without preaching and teaching, worship may become mostly a habitual religious ritual; without preaching, evangelism may become shallow or just a marketing of the church; without preaching, our service may become just good works. ${ }^{36}$

\section{Focusing on Faithful Brethren}

The preaching ministry of the pastor, however, is not a "one-man business". As discussed earlier, when there are individualistic and capitalistic cultures within the church, one finds others not availing themselves for God to use. When the church listens to only one preacher all the time, the command to commit the ministry to faithful men and women is not fulfilled. A preacher must be continually raising up people in ministry around him. Serving the Lord is a gracious privilege that must be shared with other faithful persons.

The scarcity of faithful people is recounted by the sages: "Many proclaim themselves loyal; but who can find one worthy of trust?" (Prov 20:6). This means it is possible to find a church in which there are no people worthy of trust. In the church, God expects all to share with each other the word of God. However, there is the specialized ministry of preaching and teaching which is not for all; it is not the gift of everyone. In that case, there is the need to consciously build people who are faithful to engage in this specialised ministry. At least, those who desire and are willing to preach but are not capable can be identified and supported. Those who want to be preachers must also be nurtured to be faithful people. Having the graces and gifts should be the basic requirement for those who would take preaching roles in the churches.

Paul told Timothy with a sense of urgency to commit the ministry of preaching the word to other faithful people; that is, the word of God that Timothy heard Paul preach in the midst of many witnesses (2 Tim 2:2). Pastor Timothy was not asked to commit the gift of prayer or healing or speaking of wisdom but rather what he heard Paul say. This is obviously the exposition of the word of God. The Greek word parathou (derived from the verb paratithemi) meaning "commit", "set before" "entrust" is used in the aorist imperative, which makes it more of a command. The Greek word, paratithemi and its derivatives is used 19 times in the New Testament (Matt 13:24, 31; Mk 6:41; 8:6, 7; Lk 9:16; 10:8; 11:6; 12:48; 23:46; Acts 14:23; 16:34; 17:3; 20:32; 1 Cor 10:27; 1 Tim 1:18; 2 Tim 2:2; 1 Pet 4:19). Jesus used the word in the context of planting or sowing a seed (Matt 13:24). The term is also used in relation to committing a person or oneself to the Lord (Lk 23:46; Acts 13:23; 1 Pet 4:19). Paul further uses the term in relation to sharing the word of God (1 Tim 1:18). Again, the term gives an idea of banking something valuable (Lk 12:48). To "commit" echoes an idea of an object entrusted to another's keeping for a specific period where there will be accountability in the future. To deposit something valuable in the bank connotes that the bank can be trusted to keep safely what has been deposited. The place where the valuable thing is deposited must also be a place of trust. In the same vein the person to whom the word has to be entrusted must be a person worthy of trust, hence Paul's use of "faithful men", people who can be trusted.

One cannot commit the preaching of the word of God to anyone just like that. Paul clearly commanded that the commitment should go to faithful people who are grounded on fear of God. They must be trustworthy. A faithful person is also described as a dependable, reliable person, worthy of placing one's confidence in. John Wesley said, "If I had 300 men who feared nothing but God, hated nothing but sin, and were determined to know nothing among men except

\footnotetext{
4 Clinton, The Making of a Leader, 14.

35 J.E. Means, Leadership in Christian Ministry (Grand Rapids, Michigan: Baker Book House, 1990$), 17$.

36 Donald L. Griggs, Teaching Todays Teachers to Teach (Nashville: Abingdon Press, 2003), 19.
} 
Jesus Christ and Him crucified; I would set the world on fire." ${ }^{37}$ The criteria Wesley mentions should be seen among people who are faithful. The faithful person will definitely be committed. The more committed a person is, the more effective that person can grow to influencing others. A faithful person will be productive, assiduous and devoted to duty. He or she will be a steward of the mysteries of God, so there must be consciousness of the ultimate accountability (Matt 25:14-23; 1 Cor 4:2). A faithful person can be trusted to guard sound teachings or doctrine (2 Tim 1:13), and guard the Holy Spirit who indwells him or her. A faithful person will be concerned about The Father's business of developing other disciples. The faithful person must above all have the potential to teach others. A faithful person can be trusted to achieve results.

One important virtue of a faithful person is the ability to manage life's crisis. James Fowler in his six stages of faith development describes the mature individual this way:

Conflicts and paradox are embraced as essential to the integrity of Being but are unified in a no longer paradoxical grasp of the oneness of Being. There is a capacity for a meaningful (i.e., tested and hard won) taking the role of a universal community. Active compassion for a common wealth of being is expressed, including but transcending group differences and conflicts. ${ }^{38}$

Fowler is saying that a faithful person must be a person of integrity. This means the person must be mature to know how to resolve all conflicts that come the way. Commitment can wane when they do not see leaders demonstrating commitment, when opportunities are not given to build relationships and support one another. It can wane when they struggle in unresolved conflicts.

To help sustain commitment in the church, the pastor/preacher should consider each person as a potential leader and train all to lead. The faithful learners among the lot can be set aside, just as Jesus set aside the Twelve, to be teachers in the future. If people view themselves as potential leaders, they will be motivated to learn in order that they can be of help to the group. They can have a feeling of ownership. Their initiative drive can be awakened. According to Scott Comodore, "The Shepherd model of leadership says that the way to inspire action is by empowering people. It is a pastoral care approach to leadership in that it sees the minister as the communal counsellor for the congregation. The Shepherd leader emphasizes relationships rather than roles, people rather than positions." 39

Commitment grows when people see their leaders model commitment. It grows when the leader leads by example. It grows when the leader is self-motivated, desirous to work together and build relationships, give support to one another, appreciate and respect one another, and loves to give opportunities to others even when they make mistakes. A preacher should be one who models the Christian faith for others to see and learn. People learn a lot through others' actions and words. In modelling, the preacher must set an example using the maxim, "Do to others as you would have them do to you" (Lk 6:31). This means the preacher must strive to live depending on God daily and understand the importance of seeking to grow into the likeness of Christ.

When the preacher grows in his or her own knowledge of the Bible and in prayer, he or she set good examples the learner can emulate. In the Jerusalem church, the apostles' priorities and practices to which Christians intensely devoted themselves became a way of life. They did not complain or give excuses for meeting together. They found joy in coming together always. True spiritual formation requires such commitment to consistency of practice. They were committed to Scripture (Acts 2:42), committed to one another (Acts 2:42, 44,46), committed to prayer (Acts 2:42), committed to praise and worship (Acts 2:43, 47) and committed to outreach (Acts 2:45-47). ${ }^{40}$

The Israelites found in the shema a pattern to transfer knowledge to their children (Deut 6:4-6). It was about "impressing" upon the children, that is, forcefully transferring knowledge. Likewise, the leader must impress upon the learners who desire to preach to learn. They should be ready everywhere, even when the learner walks or sits. Learning should be done at all times, when the learner wakes or sleeps. It must be accessible at doorposts, wristbands, and foreheads. Learning must also be done with all wisdom, which implies the use of the right approach and making appropriate decisions at the right time. Wisdom is a gift of the Holy Spirit. One needs the Holy Spirit's guidance therefore in all of this.

\section{The Way Forward}

How may pastor/teachers accomplish the task of committing the word of God to faithful persons who are able to teach others so that there will be a multiplicative effect in efforts at disciple making. As a way forward, the following proposals have been put forth proposed:

The Pastor/Preacher as a Person of Integrity

37 Quoted in Every Man's Bible (Carol Stream, Ill: Tyndale House Publishers, 2014), 1687.

38 James W. Fowler, "Stages in Faith: The Structural Developmental Approach," in Values and Moral Development, edited by Thomas C. Hennessy (New York: Paulist Press, 1976), 202.

39 Scott Cormode, "Multi-Layered Leadership:[SEPT The Christian Leader as Builder, Shepherd, and Gardener," Journal of Religious Leadership, 1. 2 (Fall 2002): 79.

40 Hull, The Disciple-Making Church, 67-77. 
It is said that one cannot give what one does not have. Hence, a preacher must be a person of integrity. The greatest challenge in Christian ministry is integrity. Integrity means honesty, sincerity and singleness of purpose.

The word "sincere" comes from the Latin word [sincerus] for "without wax." In the ancient world, dishonest potters would disguise cracks in low quality clay pots by covering them with wax. The pots looked perfect, but when exposed to heat, the wax would melt, exposing the cracks (and the potter's dishonesty), rendering the pots useless. ${ }^{41}$

For pastor/preachers to be able to commit the word of God to faithful men and women, they themselves have to be faithful. They have to be sincere. Integrity also comes from the word integer which means whole. Thus, the pastor/ preacher's life must be whole and not divided. God desires that the pastor/preacher's life is whole or complete in Christ. Integrity means beliefs, attitudes, words, and actions are consistent with God's nature.

The Psalmist shows us that integrity has inward and outward aspects, "Who may ascend the mountain of the Lord? Who may stand in his holy place? The one who has clean hands and a pure heart, who does not trust in an idol or swear by a false god. They will receive blessing from the Lord and vindication from God their Savior" (Psa 24:3-5; NIV). Inwardly, integrity begins from within and is based on holiness and sincerity, that is a pure heart. Outward. integrity includes behaviour, which is to be blameless. The person of integrity does nothing to cause others to stumble, that is, the pastor/preacher must have clean hands and a truthful mouth. Put in simple terms, integrity is being the same in heart, mind, and actions. Integrity is about who one is as a person, the commitments that an individual stands on, and the actions consistent with the heart and the mind. Jesus modeled integrity by living a whole and integrated life in which His inner life (intimate relationship with the Father) and outer life (His life the world saw) were consistent. This is the testimony of the Pharisees and the Herodians who came to Jesus, "Teacher, we know you are a man of integrity. You aren't swayed by others because you pay no attention to who they are; but you teach the way of God in accordance with the truth" (Mk 12:14b; NIV). The reason for which the pastor/preacher has to be a person of integrity is that, it is the only way the people they are seeking to commit the word of God to will trust them. As Bill McCartney notes, "The person of integrity is one who when he or she says something, can be trusted. When he or she gives a word, you can count on it." ${ }^{\prime 2}$ The question of trust is very critical. As Warren W. Wiersbe points out, the church is lacking in integrity and we are facing an integrity crisis. The world is asking, "Can the church be trusted". ${ }^{43}$ If the church cannot be trusted, then the claims of the church cannot be trusted either. The pastor/preacher must be a person of integrity whose word can be trusted. It is such trust that makes learners take their word serious.

\section{The Pastor/Preacher as Learner}

It is instructive to note that when Paul instructed Timothy to commit the word of God to faithful men (2 Tim 2:2), he also exhorted Timothy to study to show himself approved unto God as a workman who is not ashamed (2 Tim 2:15). Earlier in 2 Timothy 2:7, Paul had told Timothy, "Think over what I say, for the Lord will give you understanding in all things" (NRSV). God gives the understanding, but Timothy had to do the thinking. Other versions of the Bible use the word "reflect" (NIV) or "consider" (NKJV). All these words, consider, reflect and think over, connote the idea of studying. Study is not incompatible with the anointing of the Spirit. The pastor/preacher has to commit themselves to continuous learning. There is the need to be intentional about cultivating deep and honest desire and learn how to preach. The pastor/preacher is a disciple and a disciple's initial commitment is to learn from the master. To sit at Jesus' feet is a desire to excel in theological knowledge. This means that men and women can be committed to sound learning and still develop in spiritual matters.

This need for the pastor/preacher to be studious is because preaching does not just happen. Preaching is a gift based on the calling and anointing of God; but preaching is not only a gift. It is studied. John Stott gives the view that, authentic Christian preaching is both gifted and studied. Every authentic Christian preacher is gifted because he has been called, equipped, and anointed by God. ${ }^{44}$ But every gift has to be nurtured by those to whom it has been given (1 Tim. 4:4, 2 Tim. 1:6). ${ }^{45}$ So, the pastors/preachers have to nurture their gift of preaching so they can help those they are committing the word of God to also develop their gifts. John Stott further quotes a number of noted stalwarts of the faith in proving the point about the need for the pastor/preacher to be serious about studies. Stott quotes Calvin who says, "No one will ever be a good minister of the Word of God unless he is first of all a scholar", Spurgeon who says, "He who no longer sows in the study will no more reap in the pulpit,", and Philip Brooks who says "Learn to study for the sake of proof. Then your sermons will be like the leaping of a fountain, and not like the pumping of a pump." Stott

\footnotetext{
${ }_{41}$ International Leadership Institute, Regional Conference: Eight Core Values for Christian Leadership (Carrolton: International Leadership Institute, 2015), 98.

42 Cited in International Leadership Institute, Regional Conference, 99.

43 Warren W. Wiersbe, The Integrity Crisis (Nashville: Oliver-Nelson Books, 1991), 17.

44 John Stott, "The Paradoxes of Preaching" in Preach the Word: The Call and Challenge of Preaching Today, gen. ed., Greg Haslam (Lancaster: International Bible Teaching Books, 2006), 48.

45 Ibid., 49.
} 
adds Lloyd-Jones, "You will always find that the men whom God has used singularly have been those who have studied most, known their scriptures best, and given time to preparation." 46 These are the remarks of seasoned pastor/preachers who were able to commit the word of God to faithful others. If contemporary pastors/preachers are also to make similar impact, they cannot take their studies for granted.

\section{The Pastor/Preacher as Spiritual Parent}

The pastor/preacher should see himself or herself as a "Spiritual Parent". Jesus related to the crowds like a father to them. He fed the hungry, healed the sick and caused those who were proud to be ashamed of themselves. Parenting in general includes, but not limited to, the following:

1. Providing for the physical and spiritual needs of children

2. The ability to be able to communicate effectively with the child. Taking time to connect with the child on various levels. Talk and listen to the child, try to understand the child's point of view

3. Being a good teacher to the child so that the child can learn from the parent

4 Being flexible in outlook yet create good, solid boundaries for the children so that they can learn and grow with the right kind of discipline and rules

5. Showing love and care for the child.

6. Being a star example for the child. Often, children look up to someone and make that person their mentor. Parents become that mentor for their child by being everything that children are in awe of or look up to. Parents follow certain guidelines themselves so that their children can learn from practical viewing

7. Encouraging the child to develop the skills that he or she is interested in.

Like the spiritual parent, the pastor/preacher should fulfil all these expectations. If all that the parent does is to help the child grow into responsible adulthood, then the pastor/preacher's duty to help those who listen to them must aim at that. It is believed that "the successful spiritual leader can tap into his or her spirituality and encourage others to grow their own spiritual experiences." ${ }^{.77}$ If parents devote 18 years to raising children for them to be considered mature, pastor/ preachers should spend time helping faithful persons to grow in understanding spiritual realities so they can be faithful people able to teach others.

\section{The Pastor/Preacher as a Model}

Preaching is accomplished through modelling. Preachers develop not merely through the learning of correct information, but also through witnessing the life and choices of other disciples they encounter on their way. Conversations outside the pulpits must be seasoned with salt and must always tend to build others up. The Old Testament emphasizes parents teaching their children both the memorization of Scripture and conversations about the Law in daily conversations and interactions of life. A preacher who cannot memorize scripture cannot train a faithful person to memorize scripture. There is the need for learning and internalizing the Law of God (Psa 119:109). A model must also have an idea of the preferable future to guide the learner to that end. Hybels observes, "In leadership vision is the fuel that leaders run on. It's the energy that creates action; it's the fire that ignites the passion of followers." ${ }^{48}$ As a model, the pastor/preacher provides for the student what the vision or the preferable future might be. It is this preferable future that produces passion in the student to work hard to achieve. Without a sense of what will become of their effort at learning, students are not passionate about learning. But with the vision in sight, students are encouraged to stretch themselves to attain the vision. The pastor/preacher must provide that vision or preferable future through modelling. When Paul told the Corinthian church to follow his example as he followed the example of Jesus Christ (1 Cor 11:1), he was being a model to them.

\section{The Pastor/Preacher as Intentional Relationship Builder}

The pastor/preacher's relationships must spring out of a conscious commitment to build a community. Jesus intentionally selected the Twelve and formally taught them (Matt 5-7; Mk 10:1). He allowed them to observe his obedience to God as they lived together (Jn 4:27; Lk 22:39-56). In the same way, the preacher's relationships should be structured so that the learners observe how they go about their task. When opportunities are given to learners to observe intentionally, they necessarily come close to the preacher and eventually become empowered. According to T. Marshall,

Leadership that springs from a true servant nature will manifest the following characteristics: paramount aim is always the best interests of those they lead, paramount satisfaction lies in the growth and development of those

\footnotetext{
46 Ibid.

47 Duane M. Covrig, Janet Ledesma, and Gary Gifford, "Spiritual or Religious Leadership: What do you Practice? What should you Practice?" The Journal of Applied Christian Leadership (2013): 110.

48 Bill Hybels, Courageous Leadership (Grand Rapids, Michigan: Zondervan, 2002), 31.
} 
they lead, there is a willing acceptance of responsibility, has a desire for accountability, has caring love for those they lead, is willing to listen, have genuine humility of heart and because of that there is a realistic and sound judgment as to the things they can do well and the things they cannot, is willing to share power with others so that they are empowered. ${ }^{49}$

All of these can be said to happen when relationships are built up. To commit the Word to faithful people, there must be genuine relationship with them. Afterall, ministry is about relationships. Joseph Stowell notes that good relationships are indispensable to effective leadership. He quotes Kouzes and Posner as saying that, "Leadership is a reciprocal relationship between those who choose to lead and those who decide to follow. Any discussion of leadership must attend to the dynamics of this relationship. Strategies, tactics, skills, and practices are empty unless we understand the fundamentals that connect leaders and their constituents." ${ }^{50}$ Stowell continues that, "if it weren't for people, there would be no ministry. It is the inevitable commodity of our calling. Everything else is dispensable. Programs, buildings, budgets, and the like could all be peeled away, and as long as there were people, there would be a need for shepherding - the need for a shepherd who is committed to loving the sheep". ${ }^{51}$ If people are the inevitable commodity for pastoral ministry, then relationship with people is critical if they are to be brought up to their full potential. This is how important relationships are for any meaningful pastoral ministry. No wonder Emmanuel Lartey argues that the most important resource pastoral carers have are themselves and that their self-in-relationship, that is, the "ways of being with others" is the most beneficial to the people they are with. ${ }^{52}$ To commit the word of God to faithful people, the pastor/preacher must intentionally establishes loving relationships with those others. Love is critical in this because it is the key to good relationships.

\section{The Pastor/Preacher as One who Accepts the Learner's Shortcomings}

Learners do not start as perfect persons. They make mistakes so that the leader can help them out. It has been said that leadership is giving people the opportunity to fail. Various examples of this are seen in the Bible. The disciples of people failed many times and Jesus was patient with them and helped them to improve. At one time, the disciples failed to heal a man's son who had seizures. Jesus did not abandon them because of their failure but when the disciples asked Him about their inability to heal the boy, Jesus explained that it was because of their little faith (Matt 17:14-20). The incident rather became an opportunity for Jesus to teach and the disciples to learn.

The pastors/preachers should not criticize their students for not doing everything well all the time..$^{53}$ They should rather support the students to correct their mistakes and move on in developing whatever gifts and using whatever opportunities come their way to improve themselves. In doing so, individualism and the desire to have it all will be a thing of the past.

\section{CONCLUSION}

This paper has discussed the role of the pastor/preacher in disciple making. It has explained a goal of preaching among others to be a way of committing to faithful brethren who have the capacity to teach others too. It has pointed out the effects of postmodernism, capitalism, and secularization-individualism that has characterized preachers in contemporary times as a problem affecting the church, in that it has hindered this goal of preaching. The preacher's role is not about position or recognition. It has looked at discipleship as a way of engaging a person to learn from the master to become just like the master who teaches or preaches. As long as there is scarcity of faithful people, the pastor/preacher must make it an aim to build others who can also preach. This role of the pastor/preacher is critical to discipleship making. When the pastor/preacher sees themselves as a spiritual parent who helps others follow Jesus through modelling, the command to commit to faithful people can be fulfilled. Likewise, when the pastor/preacher builds relationships intentionally, insisting on faithfulness, loves learning, deals gently with the shortcomings of learners, and above all maintains integrity, the command to commit the word to faithful brethren can be fulfilled. When all these tasks are given the needed attention, the pastor/preacher can contribute their quota in discipleship making.

\footnotetext{
T. Marshall, Understanding Leadership: Fresh perspectives on the essentials of New Testament leadership, (Chichester, England: Sovereign World, 1991), 71-73.

50 Cited in Joseph M. Stowell, Shepherding the Church, Effective Spiritual: Leadership in a Changing Culture (Chicago: Moody Press, 1997), 180.

51 Stowell, Shepherding the Church, 181.

52 Emmanuel Y. Lartey, In Living Colour: An Intercultural Approach to Pastoral Care and Counselling (London: Cassell, 1997$), 42$.

53 Christopher R. Hutson, “Martha's Choice: A Pastorally Sensitive Reading of Luke 10:38-42,” Restoration Quarterly 34 (2010): 150.
} 


\section{BIBLIOGRAPHY}

Berkley, James D. Leadership Handbook of Management and Administration. Grand Rapids: Christianity Today Inc, 1994.

Boice, James Montgomery. Christ's Call to Discipleship. San Francisco: Kregel, 1998.

Brand, Chard, Charles Draper, Archie England. Holman Illustrated Bible Dictionary. Nashville, Tennessee: Holman Bible Publishers, 2003.

Brown, Frank B. “Christian Theology's Dialogue with Culture.” In Companion Encyclopaedia of Theology. Edited by Peter Byrne and Leslie Houlden. Pages 314-334. New York: Routledge, 1995.

Brown, Mark Richard. "By This They Will Know: Discipleship Principles to Transform the Church". Unpublished Thesis, Virginia: Liberty Baptist University Theological Seminary, 2012.

Cahalan, Kathleen A. "Three Approaches to Practical Theology, Theological Education, and the Church's Ministry." International Journal of Practical Theology, 9.1 (2005): 64-94.

Ciulla, J. B. editor. Ethics, the Heart of Leadership. Westport: Praeger Publishers, 2004.

Clinton, Robert J. The Making of a Leader. Colorado Springs: Navpress, 1988.

Cormode, Scott. "Multi-Layered Leadership:s[i:The Christian Leader as Builder, Shepherd, and Gardener." Journal of Religious Leadership, 1. 2 (Fall 2002): 69-104.

Covrig, Duane M., Janet Ledesma, and Gary Gifford, "Spiritual or Religious Leadership: What do you Practice? What should you Practice?” The Journal of Applied Christian Leadership (2013): 104-113.

Every Man's Bible. Carol Stream, Ill: Tyndale House Publishers, 2014.

Foster, Robert L. "Discipleship in the New Testament." date accessed 26 June 2017 in http://www.sbl-site.org/ eductional/teachingbible.aspx

Fowler, James W. "Stages in Faith: The Structural Developmental Approach." In Values and Moral Development. Edited by Thomas C. Hennessy. Pages 171-211. New York: Paulist Press, 1976.

Griggs, Donald L. Teaching Todays Teachers to Teach. Nashville: Abingdon Press, 2003.

Hermans, Christiaan A. M. "From Practical Theology to Practice-oriented Theology: The Study of Lived Spirituality and lived Religion in late Modernity." International Journal of Practical Theology 18.1 (2014): 113-126. DOI: https;//doi.org/10.1515/ijpt-2014-0009.

Hull, Bill. The Disciple-Making Church: Leading a Body of Believers on the Journey of Faith. Grand Rapids: Baker Books, 2010.

Hull, Bill. The Disciple-Making Pastor: Leading Others on the Journey of Faith. Grand Rapids: Baker Books, 2007.

"Human Resource Development Press" 2004. Accessed January 13, 2020. www.hrdpressonline.com/product_info/leadership_effectiveness_profile.htm.

Hutson, Christopher R. "Martha's Choice: A Pastorally Sensitive Reading of Luke 10:38-42,"Restoration Quarterly 34 (2010): 139-150.

Hybels, Bill. Courageous Leadership. Grand Rapids, Michigan: Zondervan, 2002.

International Leadership Institute. National Conference: Eight Core Values for Christian Leadership.

Carrolton: International Leadership Institute, 2015.

International Leadership Institute, Regional Conference: Eight Core Values for Christian Leadership.

Carrolton: International Leadership Institute, 2015.

Lamothe, Ryan. "Reflections on Pastoral Leadership in the Face of Cultural-Communal 'Ruin'." The Journal of Pastoral Theology 20.1 (2010):1-21.

Lartey, Emmanuel Y. In Living Colour: An Intercultural Approach to Pastoral Care and Counselling. London: Cassell, 1997.

Litfin, A. Duane. "The Nature of the Pastoral Role: The Leader as Completer." Bibliotheca Sacra 139.553 (1982): 57-66.

Johnston, Graham. Preaching to a Postmodern World: A Guide to Reaching Twenty-first Century Listeners. Grand Rapids: Baker Books, 2001.

MacArthur, John. Pastoral Ministry: How to Shepherd Biblically. Nashville, TN: Thomas Nelson, 2005.

Marshall, T. Understanding Leadership: Fresh perspectives on the essentials of New Testament leadership. Chichester, England: Sovereign World, 1991.

Means, J.E. Leadership in Christian Ministry. Grand Rapids, Michigan: Baker Book House, 1990.

Montgomery, Bernard Law. Memoirs of Field-Marshal Montgomery. Cleveland: World, 1958.

Newton, Gary C. Growing toward Spiritual Maturity. Wheaton: Evangelical Training Association, 1999.

Northouse, Peter G. Leadership: Theory and Practice. Thousand Oaks: Sage, 2004.

Quashie, John A. "Imposters in the Pulpits: A Critique of Preaching in Contemporary Ghanaian Christianity", Orita: I badan Journal of Religious Studies, 46.1 \& 2 (June \& December 2014): 33-49. 
Quashie John A., \& Mark S. Aidoo, Biblical Preaching in a Contemporary African Setting: An Introduction. Tema: Kabkork Publications, 2018.

Sanders, J. Oswald. Spiritual Leadership. Chicago: Moody Publishers, 2007.

Shirley, Chris. "It takes a church to make a disciple: An Integrative Model of Discipleship for the Local Church." Southwestern Journal of Theology, 50. 2 (Spring 2008): 207-224.

Stott, John. "The Paradoxes of Preaching." In Preach the Word: The Call and Challenge of Preaching Today. General editor Greg Haslam. Pages 43-51. Lancaster: International Bible Teaching Books, 2006.

Stowell, Joseph M. Shepherding the Church, Effective Spiritual: Leadership in a Changing Culture. Chicago: Moody Press, 1997.

The HarperCollins Bible Dictionary. New York: HyperCollins 1996.

Watson, D. F. "Education: Jewish and Greco-Roman." In Dictionary of New Testament Background, ed. Craig A. Evans and Stanley E. Porter. Pages 308-313. Downers Grove, IL: InterVarsity, 2000.

Weber, Robert E. Ancient-Future Evangelism: Making Your Church a Faith-Forming Community. Grand Rapids:

Baker Books, 2003.

Wiersbe, Warren W. The Integrity Crisis. Nashville: Oliver-Nelson Books, 1991.

Wilkins, Michael J. "Disciples." In Dictionary of Jesus and the Gospels. Edited by Joel B. Green, Scot McKnight, and I. Howard Marshall. Downers Grove, IL: InterVarsity, 1992.

Wilkins, Michael J. Following the Master: A Biblical Theology of Discipleship. Grand Rapids, MI: Zondervan, 1992.

“What is Disciple-Making?" Sonlife Classic, accessed May 1 2017, http://sonlifeclassic.com/what-is-disciple-making 